\title{
Cathode made of compacted silver nanoparticles for electrocatalytic carboxylation of 1-phenethyl bromide with $\mathrm{CO}_{2}$
}

\author{
Hengpan Yang a, Laxia $\mathrm{Wu}^{\mathrm{b}}$, Huan Wang a,*, Jiaxing Lu ${ }^{\mathrm{a}, \#}$ \\ a Shanghai Key Laboratory of Green Chemistry and Chemical Processes, School of Chemistry and Molecular Engineering, East China Normal University, \\ Shanghai 200062, China \\ bSchool of Chemistry and Chemical Engineering, Anqing Normal University, Anqing 246011, Anhui, China
}

\section{A R T I C L E I N F O}

Article history:

Received 2 February 2016

Accepted 29 February 2016

Published 5 July 2016

\section{Keywords:}

Electrocatalysis

Electrocarboxylation

Carbon dioxide

Benzyl bromides

Silver nanoparticles
A B S T R A C T

Silver nanoparticles prepared by the direct reduction of $\mathrm{AgNO}_{3}$ in aqueous solution were compacted into coins and used as the cathode for the electrocatalytic carboxylation of 1-phenethyl bromide with $\mathrm{CO}_{2}$. The influences of the working electrode, charge, current density and temperature were investigated. Under optimized conditions, 98\% yield of 2-phenylpropionic acid was obtained. The reaction was performed under very mild conditions and no added catalyst was required in the electrolyte. Yields that varied from moderate to excellent were also achieved with other benzyl bromides. This electrode has good stability and reusability, and the yield and selectivity of 2-phenylpropionic acid could be maintained during reuse for 10 times.

(C) 2016, Dalian Institute of Chemical Physics, Chinese Academy of Sciences. Published by Elsevier B.V. All rights reserved.
$\mathrm{CO}_{2}$ is the main greenhouse gas linked to undesirable climate change. On the other hand, $\mathrm{CO}_{2}$ is also a cheap, abundant and clean $\mathrm{C} 1$ feedstock [1]. In recent years, much effort has been made to develop effective processes for economical products by the fixation of $\mathrm{CO}_{2}$ [2-8]. Among these products, phenylpropionic acids from the carboxylation of phenyl halides with $\mathrm{CO}_{2}$ have commercial importance because of their extensive applications in pharmaceutical industry. They are used as intermediates for nonsteroidal antiinflammatory drugs (NSAIDs), like Ibuprofen, Naproxen, Ketoprofen and Flurbiprofen. Much attention has been paid to developing synthesis methods of phenylpropionic acids [9].

However, a homogeneous catalytic system for the synthesis of phenylpropionic acids involves the utilization of transition metal catalysts, such as cobalt, nickel and palladium complexes
[10-12]. Although high yields have been reported by some workers, the disadvantages are also obvious, which are that the transition metal catalysts are both expensive and hardly recyclable, which cause difficulty in practical application. Electrocatalysis was also demonstrated to be an efficient method for the synthesis of phenylpropionic acids by us $[13,14]$ and other workers $[15,16]$. It can be performed under mild conditions without a transition metal catalyst. For example, Isse and coworkers [15] reported a synthesis of benzoic acid by the electrocatalytic reduction of bromobenzene with $\mathrm{CO}_{2}$ that gave benzoic acid yields of $80 \%$.

In our former work, we investigated a route for the electrocatalytic asymmetric carboxylation of achiral 1-phenylethyl chloride with $\mathrm{CO}_{2}$ in the presence of a chiral cobalt complex. Under optimized conditions, optically active 2-phenylpropionic

\footnotetext{
* Corresponding author. Tel: +86-21-52134935; E-mail: hwang@chem.ecnu.edu.cn

\# Corresponding author. Tel: +86-21-62233491; E-mail: jxlu@chem.ecnu.edu.cn

This work was supported by the National Natural Science Foundation of China $(21203066,21373090,21473060)$.

DOI: 10.1016/S1872-2067(15)61075-0 | http://www.sciencedirect.com/science/journal/18722067 | Chin. J. Catal., Vol. 37, No. 7, July 2016
} 
acid with $37 \%$ yield and $83 \%$ ee was obtained [17]. In addition, we also prepared a [Co]@Ag composite for asymmetric carboxylation of 1-phenylethyl bromide with $\mathrm{CO}_{2}$. 2-phenylpropionic acid with 58\% yield and $73 \%$ ee was achieved at normal pressure and temperature [18]. Although optically active products were obtained with a chiral cobalt catalyst, the yield was relatively low, which need further work.

In this work, silver nanoparticles (Ag NPs) were prepared by the direct reduction of $\mathrm{AgNO}_{3}$ with hydrazine hydrate $\left(\mathrm{N}_{2} \mathrm{H}_{4} \cdot \mathrm{H}_{2} \mathrm{O}\right)$ in aqueous solution. A powder with typical metallic properties was obtained after filtration and drying. This can be easily compacted into a coin using a tablet press (Fig. 1) and used as the cathode for the electrocatalytic carboxylation of 1-phenylethyl bromide with $\mathrm{CO}_{2}$. It should be noted that this coin was prepared from pure Ag NPs powder without a support or carrier. Both the synthesis of the Ag NPs cathode and carboxylation were performed under very mild conditions, and no other catalyst was needed.

For the synthesis of $\mathrm{Ag} \mathrm{NPs}, 1.7 \mathrm{~g} \mathrm{AgNO}_{3}$ was dissolved in $100 \mathrm{~mL}$ deionized water. After $10 \mathrm{~min}$ stirring, $50 \mathrm{~mL}$ hydrazine hydrate solution $(10 \%)$ was added, and the mixture was stirred at $25^{\circ} \mathrm{C}$ for $4 \mathrm{~h}$, and Ag NPs were precipitated immediately. The precipitate was filtered, and washed with $10 \mathrm{~mL}$ water and then $10 \mathrm{~mL}$ anhydrous ethanol for 4 times, and dried for $12 \mathrm{~h}$ at $35{ }^{\circ} \mathrm{C}$ under vacuum. Ag NP powder was pressed into a coin and used as the cathode for electrolysis.

Galvanostatic electrosynthesis was performed using a direct current regulated power supply (HY3002D, HYelec $®$, China). The product yield was determined by high performance liquid chromatography (HPLC) instrument (DIONEX Ultimate 3000 pump) equipped with a UV (RS Variable Wavelength) detector. The microstructure and morphology of Ag NPs were analyzed using a Hitachi S-4800 field emission Scanning Electron Microscope (FE-SEM). X-ray diffraction (XRD) patterns were recorded by a Ultima IV X-ray powder diffractometer using $\mathrm{Cu}$ $K_{\alpha}$ radiation $(\lambda=0.15406 \mathrm{~nm})$. $\mathrm{N}_{2}$ adsorption was carried out at $-196{ }^{\circ} \mathrm{C}$ on a BELSORP-MAX instrument after outgassing the samples for $10 \mathrm{~h}$ under vacuum at $300^{\circ} \mathrm{C}$.

The resulting material was characterized by many methods. Fig. 2(d) displays the XRD patterns of an Ag NPs coin. Typical diffraction peaks of the (111), (200), (220), (311) and (222) crystal faces were observed. It is also notable that no trace of

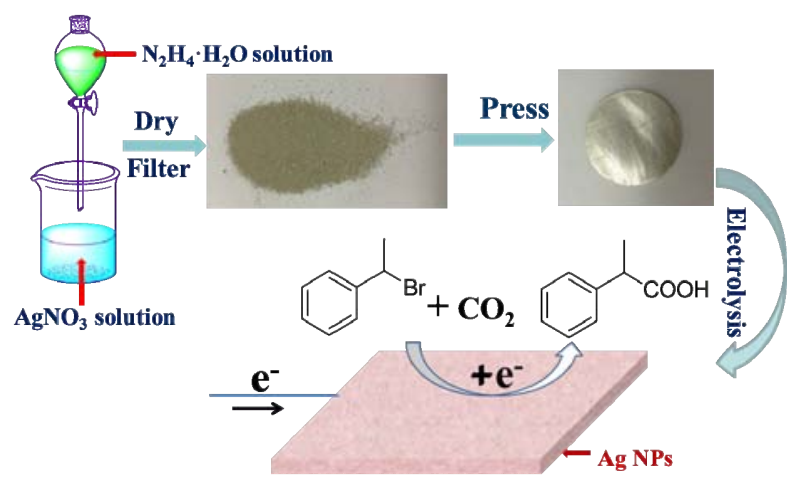

Fig. 1. Preparation of Ag NP electrode and electrocatalytic carboxylation of 1-phenethyl bromide with $\mathrm{CO}_{2}$.

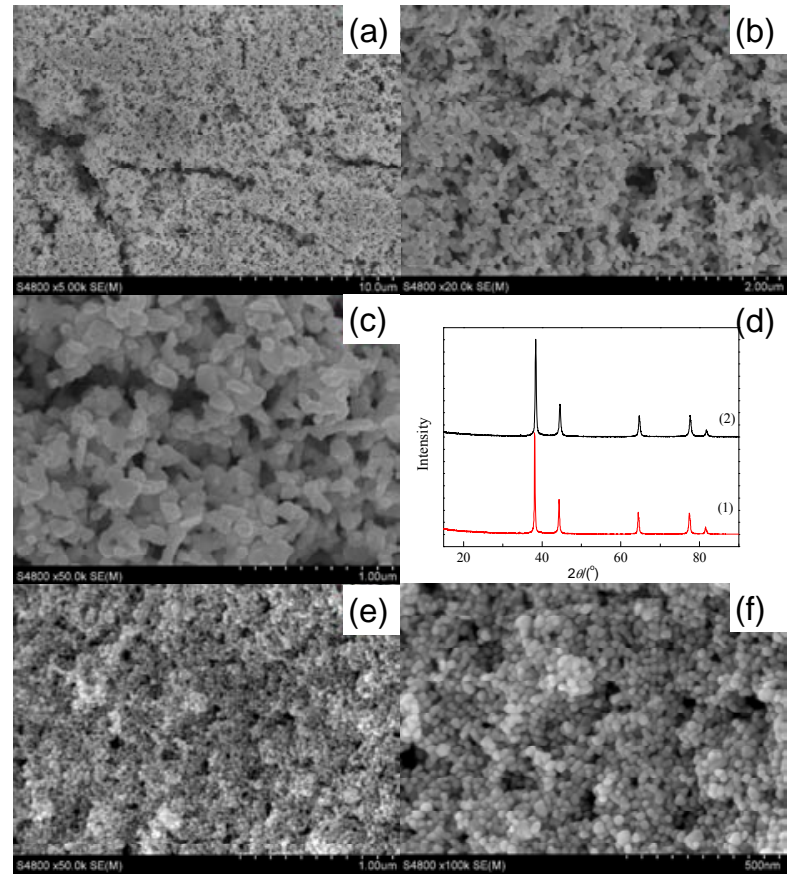

Fig. 2. Characterization results of Ag NPs. FE-SEM patterns of Ag NPs with magnifications of $5 \mathrm{k}(\mathrm{a}), 20 \mathrm{k}$ (b), and after reuse for 10 times (c); (d): XRD patterns of Ag nanoparticles before (d-1) and after reuse for 10 times (d-2); FE-SEM patterns of Ag NPs with smaller particle size (e, f).

any other substance such as silver oxide was contained in this material. The FE-SEM patterns (Fig. 2(a), (b)) of the composite revealed that this Ag NP electrode has a hierarchical structure composed of metal nanocrystallites. These elementary particles were gathered into particles of $60 \mathrm{~nm}$ and aggregated further into a macroporous solid.

Besides the preparation and characterization of this Ag NP coin, we also showed its application in catalysis. As we mentioned above, the Ag NP powder was compacted into a coin with a $2 \mathrm{~cm}$ diameter, which can be used directly as the cathode for the electrocatalytic carboxylation of 1-phenylethyl bromide with $\mathrm{CO}_{2}$. Since galvanostatic electrolysis is often simpler and preferable for large scale applications, we therefore investigated the efficiency of the electrocatalytic carboxylation under galvanostatic conditions. A typical galvanostatic electrolysis was carried out in a mixture of $0.1 \mathrm{~mol} / \mathrm{L} 1$-phenylethyl bromide (1a), $0.1 \mathrm{~mol} / \mathrm{L}$ tetraethylammonium iodide (TEAI) in 10 $\mathrm{mL}$ acetonitrile (MeCN) using an undivided glass cell with a $\mathrm{Ag}$ $\mathrm{NP}$ cathode and a sacrificial magnesium $(\mathrm{Mg})$ anode. Each measurement was performed 3-4 times. After electrolysis, the products were detected quantitatively by HPLC, which showed that 2-phenylpropionic acid (2a) was the main product. The influences of electric charge $(Q)$, current density, and the temperature were investigated to optimize the yield of $\mathbf{2 a}$. The results of the electrolysis are summarized in Table 1.

In an electrochemical reaction, the electric charge passed during electrolysis strongly influenced the yield of product $\mathbf{2 a}$ (Table 1, entries 1-4). The yield increased linearly with the charge from 1.5 to $2.5 \mathrm{~F} / \mathrm{mol}$. However, the yield did not increase further when the charge increased to $3.0 \mathrm{~F} / \mathrm{mol}$ (Table 
Table 1

Electrocatalytic carboxylation of 1-phenylethyl bromide under different conditions ${ }^{\text {a }}$.

\begin{tabular}{lcccc}
\hline Entry & $Q(\mathrm{~F} / \mathrm{mol})$ & Current density $\left(\mathrm{mA} / \mathrm{cm}^{2}\right)$ & $T\left({ }^{\circ} \mathrm{C}\right)$ & Yield ${ }^{\mathrm{b}}(\%)$ \\
\hline 1 & 1.5 & 5 & 0 & 72 \\
2 & 2.0 & 5 & 0 & 88 \\
3 & 2.5 & 5 & 0 & 98 \\
4 & 3.0 & 5 & 0 & 97 \\
5 & 2.5 & 1 & 0 & 73 \\
6 & 2.5 & 3 & 0 & 83 \\
7 & 2.5 & 7 & 0 & 89 \\
8 & 2.5 & 9 & 0 & 80 \\
10 & 2.5 & 5 & 10 & 92 \\
11 & 2.5 & 5 & 20 & 90 \\
12 & 2.5 & 5 & 30 & 87 \\
$13^{\mathrm{c}}$ & 2.5 & 5 & 0 & 51 \\
$14^{\mathrm{d}}$ & 2.5 & 5 & 0 & 96 \\
\hline
\end{tabular}

a Electrolysis were carried out in an undivided cell, cathode: Ag NPs, anode: $\mathrm{Mg}$, solvent: $10 \mathrm{~mL} \mathrm{MeCN}$, supporting electrolyte: $0.1 \mathrm{~mol} / \mathrm{L}$ TEAI, substrate concentration: $0.1 \mathrm{~mol} / \mathrm{L}$. b Determined by HPLC. ${ }^{\mathrm{c} C}$ Cathode: Ag flake. ${ }^{\mathrm{d}}$ Cathode: Ag NPs $(20 \mathrm{~nm})$.

1 , entry 4), indicating that $1 \mathbf{a}$ was already consumed entirely when $2.5 \mathrm{~F} / \mathrm{mol}$ electric charge was passed. As for the influence of the current density, the yield of 2 a improved with the current density from 1 to $9 \mathrm{~mA} / \mathrm{cm}^{2}$, reaching a maximum $(98 \%)$ at $5 \mathrm{~mA} / \mathrm{cm}^{2}$ (Table 1, entries 3,5-8). Both low and high current densities led to lower yields. The reaction temperature was also a crucial factor, which influenced the overpotential and reaction rate of the electrolysis. The highest yield of $2 \mathbf{a}$ was obtained at $0{ }^{\circ} \mathrm{C}$, a relatively low temperature. Increasing the temperature from 0 to $30^{\circ} \mathrm{C}$ did not increase the yield of 2a. On the contrary, the 2a yield decreased from $98 \%$ to $87 \%$. At a lower temperature, more $\mathrm{CO}_{2}$ was dissolved in $\mathrm{MeCN}$, and $\mathrm{CO}_{2}$ is the key reagent in this reaction, which could explain this trend [19]. Although there was a slight decline, at least $90 \%$ yield of 2 a could be achieved at $20{ }^{\circ} \mathrm{C}$, which was room temperature. Hence, our Ag NP electrode generated very good results for the electrocatalytic carboxylation of 1-phenethyl bromide with $\mathrm{CO}_{2}$ under very mild conditions. This was without the utilization of high $\mathrm{CO}_{2}$ pressure or temperature.

Using the optimized conditions in Table 1, entry 3, different cathodes were also studied to show the superiority of our Ag NP cathode. Using Ag flake as cathode (Table 1 entry 13), only $51 \%$ yield of 2 a was obtained, which was significantly lower than the 98\% yield with the Ag NP cathode, indicating that our Ag NP cathode was much more effective for the electrocatalytic carboxylation of 1-phenethyl bromide with $\mathrm{CO}_{2}$ than a common Ag flake cathode. This superiority can be attributed to the large specific surface area of Ag NPs. According to the $\mathrm{N}_{2}$ adsorption isotherm, the Ag NP coin has an average specific surface area of $8.7 \mathrm{~m}^{2} / \mathrm{g}$. Since $2 \mathrm{~g}$ Ag NPs powder was compacted into a $2 \mathrm{~cm}$ diameter coin, this gave this Ag NP cathode an actual surface area of $17.4 \mathrm{~m}^{2}$. Hence, the real surface area of the Ag NP cathode is $5.5 \times 10^{4}$ times larger than that of a common Ag flake cathode, which would provide more active sites and accelerate the reaction rate. Since Ag NPs were more efficient than a common Ag flake cathode because of its nano-structure, can Ag NPs with smaller particle size lead to an even higher yield of product? Further experiments were carried out to test this. We prepared Ag NPs with $20 \mathrm{~nm}$ particle size (Fig. 2(e), (f)) using the same method as the $60 \mathrm{~nm} \mathrm{Ag} \mathrm{NPs} \mathrm{except} \mathrm{for} \mathrm{the} \mathrm{addition}$ of polyethylene glycol in the reduction solution. Under the same conditions as Table 1, entry 3, 96\% yield of 2a was obtained at the Ag NP cathode with $20 \mathrm{~nm}$ particle size (Table 1 entry 14), which was obviously higher than that of the Ag flake cathode but almost the same as that of Ag NPs cathode with 60 $\mathrm{nm}$ particle size. This demonstrated again that nano-structure silver was beneficial to the electrocatalytic carboxylation of 1-phenethyl bromide with $\mathrm{CO}_{2}$.

It should be noted that no other catalyst was needed in our synthesis system. In addition, this Ag NP cathode can be easily recycled and cleaned after an electrolysis. Under the electrolysis conditions of Table 1 , entry 3 , repeated tests of the electrocatalytic carboxylation of 1-phenethyl bromide with $\mathrm{CO}_{2}$ were carried out using the same Ag NP cathode. As shown in Fig. 3, the yield of 2 a was maintained at around $94 \%$ even after 10 runs, revealing that this Ag NP cathode has excellent reusability. XRD and SEM were used to further investigate the stability of the Ag NP electrode. According to the XRD patterns, the composition and crystal form of the Ag NPs did not change before and after electrolysis (Fig. 2(d)). Moreover, it retained its porous structures and had the same particle size (Fig. 2(c)). In other words, the Ag NPs electrode has excellent stability and reusability, and retained its catalytic activity after at least 10 times reuse.

Encouraged by excellent results obtained with 1-phenylethyl bromide (1a), the use of different substrates was further studied. Using the reaction conditions of Table 1, entry 3 , a wide range of substituted bromides with both electron-withdrawing and electron-donating groups were tested for electrocatalytic carboxylation. The corresponding benzoic acids with moderate to good yields were obtained. As is obvious from the results summarized in Table 2, the Ag NP cathode can be applied to a wide range of substrates. Except for bromides, the Ag NP cathode was also effective for the carboxylation of 1-phenylethyl chloride, and $86 \%$ yield of

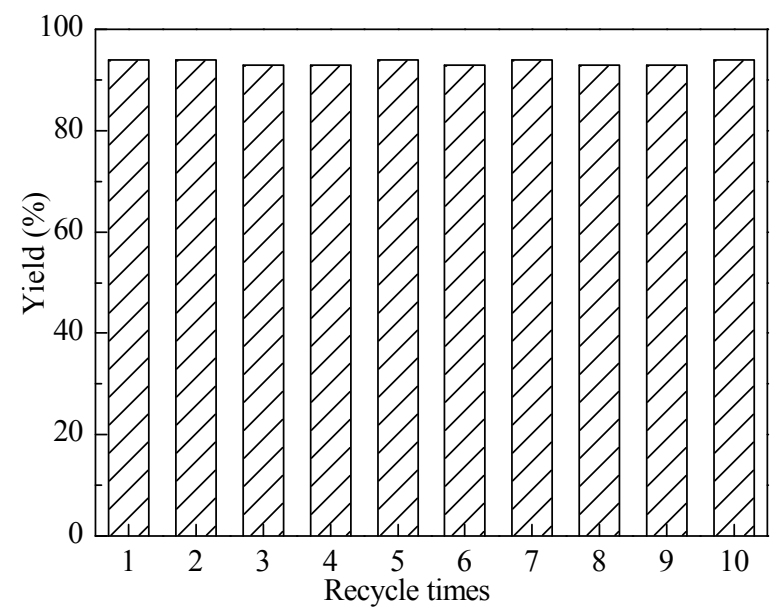

Fig. 3. Reuse of Ag NPs cathode. Reaction conditions are the same as Table 1 , entry 3. 
Table 2

Electrocatalytic carboxylation of different substrates with the Ag NP cathode ${ }^{\text {a. }}$.

Entry

a Electrolysis were carried out under the same conditions as Table 1, entry $3 .{ }^{\mathrm{b}}$ Determined by HPLC.

2-phenylpropionic acid was obtained using the same reaction condition as 1-phenylethyl bromide (Table 2, entry 7).

In conclusion, a compacted Ag NP cathode was prepared using a simple method without any support or carrier. This was effective for the electrocatalytic carboxylation of 1-phenethyl bromide with $\mathrm{CO}_{2}$. Under optimized conditions, 2-phenylpropionic acid with $98 \%$ yield was obtained. Moderate to good yields of benzoic acids were achieved with other substrates. This Ag NP cathode has remarkable stability and reusability, shown by that the yield of 2-phenylpropionic acid did not decrease significantly after at least 10 times reuse. Considering its easy preparation, high effectiveness and excellent reusability, this Ag NP cathode has potential for practical application.

\section{References}

[1] T. Sakakura, J. C. Choi, H. Yasuda, Chem. Rev., 2007, 107, 2365-2387.

[2] C. A. Huff, M. S. Sanford, J. Am. Chem. Soc., 2011, 133, 18122-18125.

[3] Z. F. Zhang, S. Q. Hu, J. L. Song, W. J. Li, G. Y. Yang, B. X. Han, ChemSusChem, 2009, 2, 234-238.

[4] S. G. Liang, H. Z. Liu, T. Jiang, J. L. Song, G. Y. Yang, B. X. Han, Chem. Commun., 2011, 47, 2131-2133.

[5] F. Shi, Y. Q. Deng, T. L. SiMa, J. J. Peng, Y. L. Gu, B. T. Qiao, Angew. Chem. Int. Ed., 2003, 42, 3257-3260.

[6] B. Yu, H. Y. Zhang, Y. F. Zhao, S. Chen, J. L. Xu, C. L. Huang, Z. M. Liu, Green Chem., 2013, 15, 95-99.

[7] O. Jacquet, C. Das Neves Gomes, M. Ephritikhine, T. Cantat, ChemCatChem, 2013, 5, 117-120.

[8] M. North, R. Pasquale, C. Young, Green Chem., 2010, 12, 1514-1539.

[9] A. A. Isse, A. D. Giusti, A. Gennaro, L. Falciola, P. R. Mussini, Electrochim. Acta, 2006, 51, 4956-4964.

[10] P. L. Fabre, O. Reynes, Electrochem. Commun., 2010, 12, 1360-1362.

[11] A. Gennaro, A. A. Isse, F. Maran, J. Electroanal. Chem., 2001, 507, 124-134.

[12] J. Damodar, S. R. K. Mohan, S. R. J. Reddy, Electrochem. Commun., 2001, 3, 762-766.

[13] L. X. Wu, H. Wang, Y. Xiao, Z. Y. Tu, B. B. Ding, J. X. Lu, Electrochem. Commun., 2012, 25, 116-118.

[14] Y. Xiao, B. L. Chen, H. P. Yang, H. Wang, J. X. Lu, Electrochem. Commun., 2014, 43, 71-74.

[15] A. A. Isse, C. Durante, A. Gennaro, Electrochem. Commun., 2011, 13, 810-813.

[16] A. A. Isse, A. Gennaro, Chem. Commun., 2002, 2798-2799.

[17] B. L. Chen, H. W. Zhu, Y. Xiao, Q. L. Sun, H. Wang, J. X. Lu, Electrochem. Commun., 2014, 42, 55-59.

[18] H. P. Yang, Y. N. Yue, Q. L. Sun, Q. Feng, H. Wang, J. X. Lu, Chem. Commun., 2015, 51, 12216-12219.

[19] A. Gennaro, A. A. Isse, E. Vianello, J. Electroanal. Chem., 1990, 289, 203-215.

\section{Graphical Abstract}

Chin. J. Catal., 2016, 37: 994-998 doi: 10.1016/S1872-2067(15)61075-0

Cathode made of compacted silver nanoparticles for electrocatalytic carboxylation of 1-phenethyl bromide with $\mathrm{CO}_{2}$

Hengpan Yang, Laxia Wu, Huan Wang *, Jiaxing Lu *

East China Normal University; Anqing Normal University

A cathode made of compacted Ag nanoparticles was prepared with a simple method and used for the electrocatalytic carboxylation of 1-phenethyl bromide with $\mathrm{CO}_{2}$. It has excellent efficiency, high stability and remarkable reusability and was active under very mild conditions.

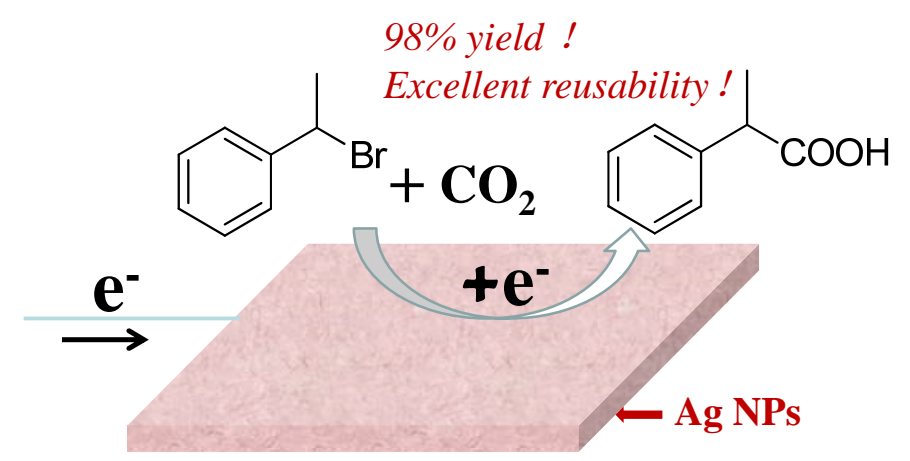




\title{
无负载的纳米银电极：一种用于 1-溴乙基苯与 $\mathrm{CO}_{2}$ 电羧化的高效催化剂
}

\author{
杨恒攀 ${ }^{\mathrm{a}}$, 吴腊霞, 王 欢 ${ }^{\mathrm{a},}{ }^{*}$, 陆嘉星 ${ }^{\mathrm{a}, \#}$ \\ a华东师范大学化学与分子工程学院, 上海市绿色化学与化工过程绿色化重点实验室, 上海 200062

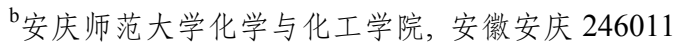

摘要: $\mathrm{CO}_{2}$ 作为主要的温室气体, $\mathrm{CO}_{2}$ 固定利用引起了广泛的关注, 同时它还是一种丰富无毒的 $\mathrm{C} 1$ 资源, 将其作为原料合 成高附加值的化学品, 不仅可以缓解温室效应, 而且还可以缓解能源危机, 具有重要的经济和战略意义. 在 $\mathrm{CO}_{2}$ 的资源化 利用中, 制备 2-苯基丙酸意义重大. 2-苯基丙酸是一种重要的医药中间体, 可用于合成布洛芬、酩洛芬等用途广泛的药剂. 因此, 其制备方法引起了人们的广泛关注.

在典型的合成 2-苯基丙酸均相催化体系中, 经常使用 $\mathrm{Co}, \mathrm{Ni}$ 和Pd 等过渡金属催化剂, 虽然得到的目标产物产率较高, 但催化剂成本高, 且很难循环使用, 从而限制了其实际使用.

电催化法为 2-苯基丙酸的合成提供了一条新的途径. 本课题组利用手性钴配合物作为催化剂电羧化不对称合成了手 性 2-苯基丙酸, 其产率和 ee 值分别为 37\% 和 $83 \%$. 此外, 我们还制备了 Co 负载的纳米 $\mathrm{Ag}$ 电极, 以其为工作电极不对称 羧化 1-溴乙基苯与 $\mathrm{CO}_{2}$ 反应, 得到目标产物 2-苯基丙酸的产率为 $58 \%$, ee 值为 $73 \%$.

在前期工作的基础上, 本文利用无负载的纳米银电极 $(\mathrm{Ag} \mathrm{NPs})$ 为工作电极, 电催化 1-溴乙基苯与 $\mathrm{CO}_{2}$ 羧化制备 2-苯 基丙酸. 银纳米电极是利用水合肼还原 $\mathrm{AgNO}_{3}$ 溶液经抽滤、干燥、压片而成. 为了研究 $\mathrm{Ag} \mathrm{NPs}$ 催化 $\mathrm{CO}_{2}$ 与 1-溴乙基苯反 应, 在一室型电解池中, 以 $\mathrm{Ag} \mathrm{NPs}$ 为阴极, 镁电极为牺牲阳极, 以 $\mathrm{CH}_{3} \mathrm{CN}-\mathrm{TEAI}(0.1 \mathrm{~mol} / \mathrm{L})$ 溶液为电解质溶液, 底物浓度为 $0.1 \mathrm{~mol} / \mathrm{L}$, 饱和 $\mathrm{CO}_{2}$ 的氛围下进行恒电流电解, 经后处理, 可得目标产物 2-苯基丙酸. 为了提高 2-苯基丙酸的产率, 我们探 讨了工作电极、电解电量、电流密度以及反应温度等条件对反应的影响, 从而得到优化条件为反应温度 $0{ }^{\circ} \mathrm{C}$ 、电解电量 2.5 $\mathrm{F} / \mathrm{mol}$ 、电流密度 $5 \mathrm{~mA} / \mathrm{cm}^{2}$, 此时 2-苯基丙酸的产率可达 $98 \%$.

在优化条件下, 我们还研究了一系列苯基卤代物, 如犋化茮、澳苯、 $\alpha$-溴苯乙酸、2-澳代菜、二苯基溴甲烷和1-氯乙基 苯的电羧化反应. 反应后可以得到相应的羧酸, 并取得较好的收率 $(67 \%-88 \%)$. 结果表明, 纳米银电极对催化该类反应具 有很好催化活性和普适性. 本文所采用的条件都比较温和, 无需高温或高压.

在最优条件下, 所制纳米银电极可重复使用至少 10 次, 且保持催化活性不变. 经过 X 射线衍射和扫描电镜表征发现, 重复使用后纳米银电极的组成和微结构都保持不变. 因此, 该纳米银电极具有制备方法简单、催化活性高, 稳定性好等特 点, 具备一定的应用前景.

关键词: 电催化; 电羧化; 二氧化碳; 芐基溴化物; 纳米银粒子

收稿日期: 2016-02-02. 接受日期: 2016-02-29. 出版日期: 2016-07-05.

*通讯联系人. 电话: (021)52134935; 电子信箱: hwang@chem.ecnu.edu.cn

\#通讯联系人. 电话: (021)62233491; 电子信箱: jxlu@chem.ecnu.edu.cn

基金来源：国家自然科学基金 $(21203066,21373090,21473060)$.

本文的英文电子版由Elsevier出版社在ScienceDirect上出版(http://www.sciencedirect.com/science/journal/18722067). 